7. Reprod. Fertil. (1963) 5, 347-358

\title{
RELATION BETWEEN FRUCTOSE CONTENT OF SEMEN AND FERTILITY IN MAN
}

\author{
G. SCHIRREN \\ Universitäts-Hautklinik-Poliklinik, Martinistrasse 52, \\ Hamburg 20, Germany
}

(Received 8th October 1962)

Summary. Biochemical and morphological examinations on human semen have been carried out on more than 2000 patients at a fertility clinic, and the findings are reported in this paper. The fructolysis of human semen depends on the presence of normal spermatozoa; centrifuged cell-free seminal plasma shows no fructolysis.

The relationship between fructose content and the sperm count of the semen has been investigated. It was found that the absolute fructose concentration was inversely proportional to the number of spermatozoa. The normal fructose value was found to be 1200 to $4500 \mathrm{\mu g} / \mathrm{ml}$; values below $1200 \mathrm{\mu g} / \mathrm{ml}$ were considered to be pathological and due to inflammation of the seminal vesicles or to androgen deficiency. The variation in fructose content in a normal patient $(1200$ to $4500 \mathrm{\mu g} / \mathrm{ml}$ ) was never found to be below $1200 \mathrm{\mu g} / \mathrm{ml}$. The fructose concentration was diminished following abstinence of 8 to 14 days or more.

The average fructose value is higher in groups of young patients than in groups of aged patients. Particular attention was given to the group of patients with 'normospermia with postpubescent interstitial-cell insufficiency' in this investigation. These patients are infertile but aftcr treatment with methyltestosterone or chorionic gonadotrophin the fructose value returned to normal and the patients became fertile.

\section{INTRODUGTION}

Among the many identified substances in human semen, fructose is becoming increasingly significant. Since the research of McCarthy, Stepita, Johnston \& Klliani (1928 - cited by Mann, 1954), Ivanov (1931), as well as Huggins \& Johnson (1933), who can be considered as the pioneers in the field of semen biochemistry, it was known that semen contained a reducing substance. While this substance was constantly referred to as glucose, Mann succeeded in 1945 (see Mann, 1946a, b) in proving through chemical methods that the sugar in semen was fructose. Mann conducted his research primarily on animal semen, but this research has its own special significance for the biochemistry of human semen, and it can be said that Mann's proof of fructose in semen opened a new chapter in fertility research and its investigation in man (see Kimmig, 1956, 1959; Nowakowski \& Schirren, 1956; Schirren, 1955, 1961). 
The research proposed by Mann and his associates was not only to test for fructose in different animals (stallion, bull, ram, rabbit, guinea-pig, rat), but also to establish a relationship between the fructose content in semen and the nature of certain endocrine anomalies. Thus Mann \& Parsons (1947) introduced the so-called fructose test, which was further developed by Mann, Lutwak-Mann \& Price (1948), Mann, Davies \& Humphrey (1949) as well as Mann \& Parsons (1950). This test depended on the observation that no fructose could be detected in the accessory glands of various male domestic animals, while they were infantile; fructose was always detected in pubescent animals. Further research showed that castration of pubescent animals always reduced the concentration of fructose, whereas treatment with testosterone produced an increase in the fructose concentration in semen and in the accessory glands.

These results from animal experimentation found their first application to man by Landau \& Loughead (1951), who were able to show a decreased fructose concentration in men with symptoms of androgen deficiency (in this case eunuchoid patients); a return of the fructose concentration to normal in these cases was attained by treatment with testosterone, so that here again a relationship probably existed between the fructose concentration and the testosterone concentration. Before continuing with further findings, it is necessary to consider the test for fructose in human semen under normal conditions.

\section{OBSERVATIONS AND DISCUSSION}

\section{FRUCTOLYSIS INDEX}

Fructose analysis of human semen has often been carried out. Attention is called to the works of Harvey (1951), Davis \& McCune (1950), Eichenberger \& Goossens (1951), Gropper \& Nikolowski (1954), Raboch \& Hradec (1954), Vasterling (1958), Tyler (1955), as well as Schirren (1955, 1961). All used primarily the same methods, which were based on the analytical method of Roe and on the modified method of Davis \& McCune (1950); the test is basically colorimetrical analysis of the colour reaction between fructose and resorcin (see Schirren, 1955) (Text-figs. 1 to 3).

We have been able to carry out a fructose analysis on approximately 2000 male patients up to the present time. We were interested particularly in fructolysis and the fructolysis index, as well as the question whether spermatozoa are capable of fructolysis. A survey of our results (given below) shows that distinct differences existed among the various diagnostic groups (Table 1), which were based on morphological differentiation in fertility diagnosis. The result was that the largest fructolysis index $(520 \mu \mathrm{g})$ was found in the normosperm group, while the oligosperm group displayed a very low fructolysis index $(215 \mu \mathrm{g})$.

It is thus clearly shown that fructolysis in man (i.e. the break-down of fructose in seminal plasma) is dependent upon the presence of spermatozoa. This viewpoint was verified with similar experimental research on seminal plasma containing spermatozoa (see Text-fig. 2). It was, however, necessary in these tests to add penicillin in small amounts $(0.5 \mathrm{mg} / \mathrm{ml} \mathrm{semen})$ to the seminal 


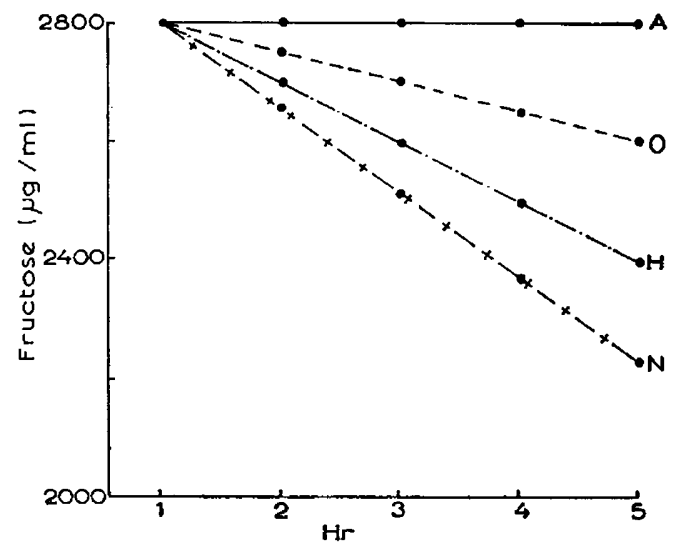

Text-rig. 1. Fructolysis in human semen. $A=$ azoospermia; $\mathrm{O}=$ oligospermia; $\mathrm{H}=$ hypozoospermia; $\mathrm{N}=$ normospermia.

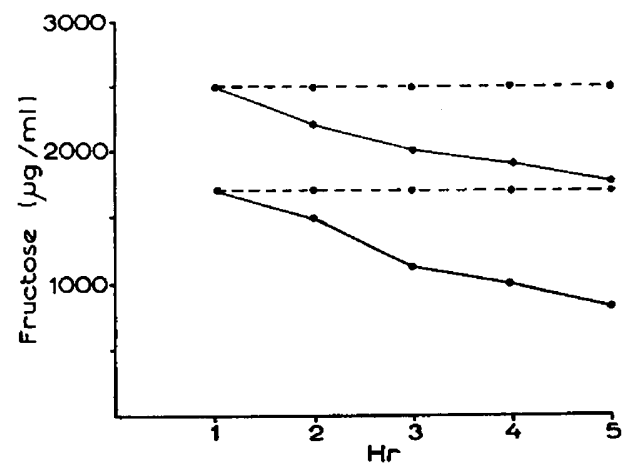

TexT-FIG. 2. Fructolysis in two cases of normospermia. spermatozoa). - .- Seminal plasma (without spermatozoa).

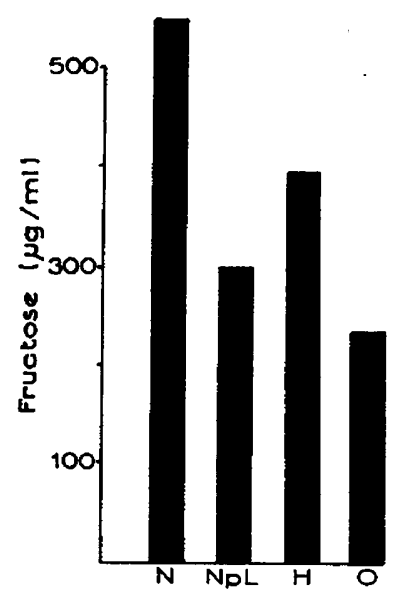

Text-Fig. 3. Fructolysis in human semen (5-hr levels). $\mathrm{N}=$ normospermia; $\mathrm{NpL}=$ normospermia with postpuberal Leydig-cell deficiency; $\mathbf{H}=$ hypozoospermia; $\mathrm{O}=$ oligospermia. 
plasma in order to prevent bacterial synthesis of fructose. Penicillin was not added in the experiments of Eichenberger \& Goossens (1950); most likely their observed fructolysis in seminal plasma lacking spermatozoa was a fructolysis by bacteria.

\section{FRUCTOSE AND NUMBER OF SPERMATOZOA}

Correlation has often been assumed to exist, without direct evidence, between fructose concentration in seminal plasma and certain clinical groupings based on sperm abnormalities (Gropper \& Nikolowski, 1954; Eichenberger \& Goossens, 1950; McGullagh \& Schaffenburg, 1951). No relationship can be shown between the concentration of fructose and the volume of ejaculate, as long as the semen in question is 'normal' (McCullagh \& Schaffenburg, 1951), endocrinological cases will not be considered here, but will be discussed in detail later. Nor is it possible to verify the correlation between the number of

TABLE 1

SURVEY OF FERTILITY DISTURBANGES DIAGNOSED IN THE UNIVERSITY SKIN GLINIC OF HAMBURG-EPPENDORF FROM 1951 TO 1959, ARRANGED IN ORDER OF GLINICAL DIAGNOSIS

\begin{tabular}{l|r}
\multicolumn{1}{c|}{ Diagnosis } & No. cases \\
\hline Normospermia & 726 \\
Hypospermia & 242 \\
Oligospermia & 629 \\
Hypokinesis & 42 \\
Aspermatic occlusion & 61 \\
Azoospermia, aspermia (eunuchs, cryptorchids, etc.) & 194 \\
Primary testicular atrophy (trauma) & 154 \\
Primary testicular atrophy (infection) & 4 \\
Primary testicular hypoplasia (unknown etiology), male & 23 \\
Klinefelter syndrome (female) & 22 \\
Secondary testical hypoplasia & 3 \\
Normospermia with postpubescent Leydig-cell & 58 \\
insufficiency & 2158 \\
\hline Total No. cases & \\
\hline
\end{tabular}

spermatozoa and the precentage of fructose claimed by Gropper \& Nikolowski (1954). Moreover, working in collaboration with Stossier (1960), we found notable lower percentages of fructose with increasing numbers of spermatozoa. It was possible to connect these results with the appearance of oestrogenic substances in seminal plasma, which was first reported by Schaffenburg \& McCullagh (1954). The decreased concentration of fructose in seminal plasma must be traced back to a suppression of testosterone production in the Leydig cells due to suppression of ICSH production by the anterior lobe of the pituitary gland, caused by oestrogenic substances. This hypothesis has not yet been proven, but according to present-day research it may be of value. The proof of this idea can only be attained with extreme difficulty because the amount of oestrogenic material in semen is exceptionally small and large amounts must be collected from seminal plasma for the analysis. Harvey (1951) had assumed that the fructose in human ejaculate would be at least partially consumed, most likely 
just before ejaculation. Should something like this actually take place, then one would have to expect an increase in the percentage of lactic acid in the ejaculate; according to Mann's research in 1946, this is not the case. Kimmig indicated in 1955 that the synthesis of fructose in the seminal vesicles could be

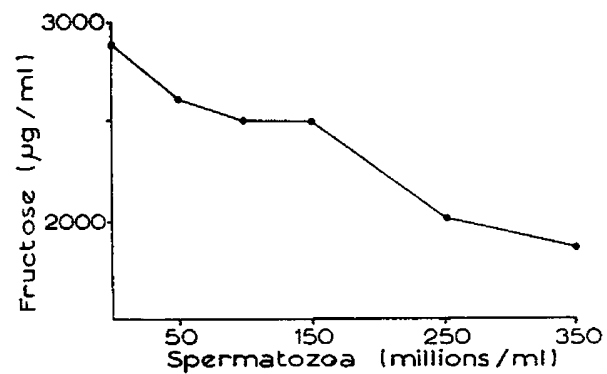

Texr-fig. 4. Fructose content of human semen and sperm count.

checked by large doses of oestradiol in animal experiments and that the operative mechanism must be considered either a direct oestrogen-testosterone antagonism or else an effect by way of the anterior lobe of the pituitary gland (Text-fig. 4).

\section{FRUCTOSE FLUCTUATION}

The figures for fructose concentration as recorded by investigators (Table 2) seem to differ at first glance. However, a closer analysis shows that, with the mounting number of cases studied, increasing concentrations of fructose were

TABLE 2

FRUCTOSE CONTENT OF SEMINAL PLASMA (TAKEN FROM THE LITERATURE)

\begin{tabular}{r|l|r}
\hline $\begin{array}{c}\text { No. } \\
\text { cases }\end{array}$ & \multicolumn{1}{c|}{ Author } & $\begin{array}{r}\text { Fructose concentration } \\
(\mu g / m l)\end{array}$ \\
\hline 123 & Harvey (1951) & 50 to 6400 \\
5 & Eichenberger \& Goossens (1950) & 1000 to 4000 \\
24 & Landau \& Loughead (1951) & 1350 to 8070 \\
47 & Raboch \& Hradec (1954) & 610 to 7600 \\
65 & Gropper \& Nikolowski (1954) & 1500 to 3000 \\
59 & Nowakowski \& Schirren (1956) & 1200 to 2500 \\
& McCullagh \& Schaffenburg (1951) & 2000 to 8000 \\
20 & Davis \& McCune (1950) & 590 to 5100 \\
70 & Tyler (1955) & 400 to 5080 \\
400 & Vasterling (1958) & 1000 to 5000 \\
125 & Vaishwanar (1958) & 690 to 6380 \\
2049 & Schirren (1955-1959) & 80 to 4500 \\
& & \\
\hline
\end{tabular}

observed, which was not a reasonable result (Harvey, 1951; Schirren, 1955, 1961).

Table 2 contains all available figures for fructose concentration; it is by no means a selection. We will consider as a 'normal concentration' a fructose concentration between 1200 and $4500 \mu \mathrm{g} / \mathrm{ml}$. All lower figures for fructose 
concentration must be considered pathological; this is to say, such concentrations normally result in infertility. The relationship between the fructose concentration in human seminal plasma and the function of Leydig cells will be more fully investigated later (see Nowakowski \& Schirren, 1956). At this point, reference should be made to the fact that lower fructose concentration always suggested a decrease testosterone production by the Leydig cells, when there was no sign of inflammation of the prostate region or seminal vesicles.

The reduced fructose values, which we obtained, are not to be considered as due to errors of technique in the fructose determination, because double determinations, whose margin of error was approximately $5 \%$, had been carried out; therefore fructose values for up to $1000 \mathrm{\mu g} / \mathrm{ml}$ would approximately amount to $50 \mu \mathrm{g}$. Other values can be discarded because they are considered as physiological fluctuations of the fructose concentrations from the same patients, in whose cases repeated ejaculate controls were always carried out, which constantly produced the same results as noted at the start. The work of Tyler (1955) can be mentioned here in support of the original idea; he found that an experimental fructose value would be reproduced within 60 days by a control. Tyler (1955) was able to determine the fluctuations in fructose concentrations of his patients in repeated examinations; these fluctuations were within our 'normal range' (1200 to $4500 \mathrm{\mu g} / \mathrm{ml}$ ); however, they never showed such reduced fructose values as those that we were able to demonstrate in the cases of normospermia with postpuberal Leydig-cell insufficiency.

After it had been shown by Stossier (1960), that certain relationships exist between sexual abstinence and the morphological quality of human semen, it seemed advisable to follow up the relationship between fructose concentrations in seminal plasma and sexual abstinence. Gropper \& Nikolowski (1954) had assumed that close relationships existed here. He thought that a reduced fructose concentration would suggest a short abstinence and proposed this point as a necessary criterion in the judgment of paternity cases, because one could establish sexual abstinence by means of a reduced fructose concentration in case of a false testimony by the person in question. Stossier's (1960) own experiments showed that his assumption could not be confirmed. Furthermore, the only relationship that exists is that fructose concentration significantly decreases with a longer abstinence (from 8 days on up to 14 days and more). Details can be seen in Table 3.

\section{FRUCTOSE AND AGE}

A more positive relationship can be shown between the fructose content of seminal plasma and age. Nowakowski \& Schmidt (1959) reported similar experiments, which led to the same conclusion. Their work included also the age groups between 61 and 70 years, which must be excluded from our own work, because we were concerned with fertility. In this way Nowakowski \& Schmidt's experiments present a very important supplement and verification. As shown by Text-fig. 5 , the fructose content of human seminal plasma decreases continuously with age. In other words, we find here a relationship between testosterone production and the fructose content of seminal plasma again 
verified, because an involution of the reproductive glands appears with age and with it a decreased testosterone production by the Leydig cells. There Belonoschkin's (1954) concept of a 'climaterium virile' has been experimentally supported and is consistent with the observations on the effect of ageing (see Nowakowski \& Schmidt, 1959). Tillinger (1957) was able to show in testis sections from 227 men that a continuous diminution of the Leydig cells with

TABLE 3

\begin{tabular}{c|c}
$\begin{array}{l}\text { FRUCTOSE CONCENTRATION IN SEMINAL } \\
\text { PLASMA IN } \\
\text { RELATION } \\
\text { ABSTINENCE }\end{array}$ \\
\hline Days of abstinence & $\begin{array}{c}\text { Average fructose level } \\
(\boldsymbol{\mu g} / \mathrm{ml})\end{array}$ \\
\hline & 2815 \\
\hline 1 & 2582 \\
3 & 2599 \\
4 & 2767 \\
5 & 2842 \\
6 & 2948 \\
7 & 2423 \\
8 & 2560 \\
9 & 2551 \\
10 & 2334 \\
11 & 2255 \\
12 & 2417 \\
13 & 2101 \\
14 & 1986 \\
\hline
\end{tabular}

age is to be observed. In a similar way, the 17-ketosteroid values in urine regress with age as seen in the work of Hamburger (1948), as well as Johnsen (1956) and others.

FRUCTOSE AND ANDROGEN CONCENTRATION (INTERSTITIAL-CELL FUNCTION)

The proven relationships between fructose content of seminal plasma and testosterone production have been previously referred to in Mann's (1946) animal

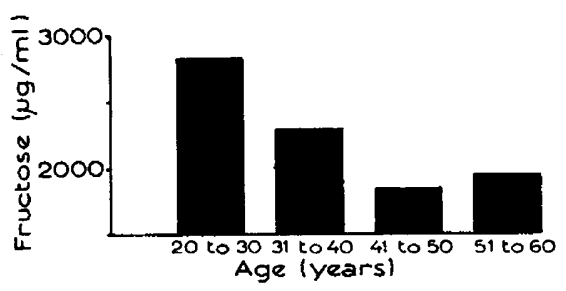

Text-Fig. 5. Seminal fructose content and age.

experimentation. After Landau \& Loughead (1951) verified these results on human beings for the first time with four patients (eunuchs), it became of great interest to check these results again on a large basis. Nowakowski \& Schirren (1956) were able to carry out in 1955 investigations concerning the fructose content of seminal plasma and interstitial-cell function 
in thirty-one patients, and they arrived at several conclusions, whose significance presented new aspects in fertility diagnosis. With detailed examination on seven patients, whose semen morphologically showed a 'normospermia', but whose fructose tests indicated abnormally low concentrations, they found that in these cases a so-called postpubescent interstitial-cell insufficiency must exist as a result of an ICSH deficiency. The low concentration of fructose was their only pathological result; all other functional endocrinological tests, including the analysis of gonadotrophin and the 17-ketosteroids in urine, produced normal results.

The peculiarity in these cases was that they presented no extraordinary clinical symptoms, that the ejaculate showed a normospermia with a reduced fructose concentration, and some were childless for several years of marriage. They presented themselves for examination for this reason. In all cases, an increase in the fructose concentration was successfully achieved not only by

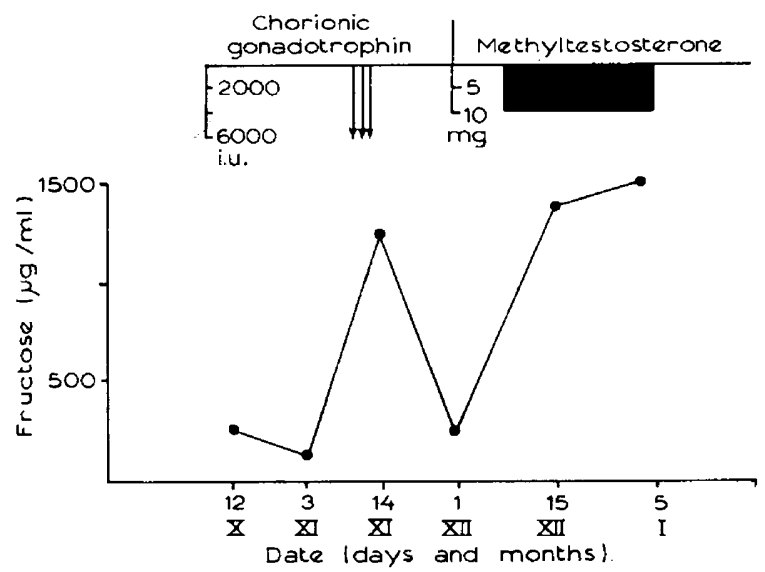

TExT-FIG. 6. Effect of gonadotrophin and methyltestosterone therapy in normospermia and postpuberal Leydig-cell deficiency. Note fructose content in semen before and the increase during hormone therapy.

means of chorionic gonadotrophin treatment but also by administration of methyltestosterone (Text-figs. 6 and 7). During this treatment there were no morphological changes in the spermiogram. These patients were placed on permanent treatment with methyltestosterone applied sublingually or buccally, i.e. they received 5 to $10 \mathrm{mg}$ daily during the first 14 days of their wives' cycles and a therapeutic pause was called during the second half of the cycle. In this way an overdose of testosterone was prevented. From the seven cases that Nowakowski \& Schirren (1956) were able to report, five were kept under observation for several years. All five cases showed a positive reaction in their fructose concentrations in seminal plasma since receiving testosterone; in four cases the desired pregnancy resulted - three healthy children were born, while the fourth case resulted in abortus mens $I V$.

In subsequent years, additional cases of normospermia with postpubescent interstitial-cell insufficiency have been diagnosed in the Dermatological University Clinic, Hamburg-Eppendorf. They have been examined in the same 
way and placed under methyltestosterone treatment in the aforesaid manner. Particulars concerning the increase of fructose in semen with hormone treatment will be given in future reports. Inositol concentrations and phosphate activity will also be given in connexion with the fructose concentrations; hormone activity on the various substances in seminal plasma will be in this way more clearly presented. Thorough clinical examinations of these patients showed no conspicuous symptoms: particularly the penis and testicles were of normal size and an adequate secondary hair growth existed with normal distribution, so that this disturbance could be well overlooked without the knowledge of the biochemical findings. The reduction of the fructose concentration in semen was not traced back to an organic disease (e.g. inflammation) of the site of fructose
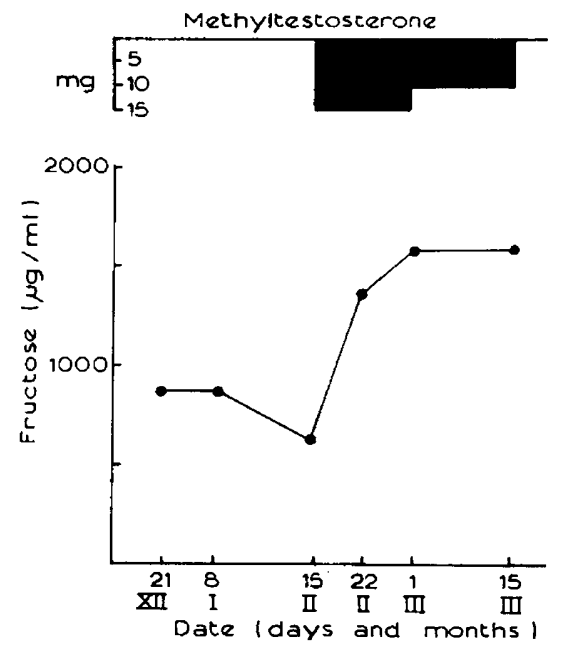

TEXT-FIG. 7. Effect of testosterone therapy in normospermia and postpuberal Leydig-cell deficiency.

synthesis; in addition, the possibility of a fluctuation in fructose concentration, such as Tyler (1955) had observed, can be discarded.

Therefore, after an eliminating diagnosis was made, it was necessary to suspect an isolated ICSH deficiency. The isolated prepubescent ICSH deficiency was demonstrated for the first time in man by McCullagh et al. (1953) on the grounds of similar hormone analysis. Pasqualini reported in 1953 a 24-year-old man, who presented eunuchoid symptoms, but whose testicles showed a normal spermatogenesis; Pasqualini termed his own observation "Sindrome hipoandrogenico con gametogenesis conversada", while McCullagh et al. (1953) chose the expression "Fertile eunuchs". The following detailed description is concerned with a postpuberal type of rcsH deficiency (see Nowakowski \& Schirren, 1956).

W.K. ... born 1.12.25 Protocol No. 6909

Childhood diseases: measles, scarlet fever and whooping cough. Otherwise uneventful medical history.

Patient complained for some time of 'circulatory disturbances' with a tendency to collapse. Five years married, childless. 
Examination findings: Clinically no conspicuous findings to report. RR 110/90 Testicle volumes under the normal margin, of hard consistency. Epididymis and ductus deferens inconspicuous. Prostate gland normal. Larynx ossification appropriate to age and skeletal maturity. No osteoporosis. Sella turcica inconspicuous. Double-blood-sugar and intravenous-insulin loading tests normal.

Basal metabolism $+1 \%$.

Liver function tests within normal range. Several bad teeth. Gonadotrophin secretion in urine (determined by the method of Klinefelter, Albright \& Griswold, 1943): 13.2 mouse units/24 hr.

Spermiogram: Amount-2.5 ml; pH 7.0; smell-sweet chestnut; colourwhite; consistency-viscous; field of vision-very many spermatozoa of which $40 \%$ showed energetic motility, 30\% moderate motility and 30\% no motility, many round cells; sperm count $-68,000,000 / \mathrm{ml}$; fructose$700 \mu \mathrm{g} / \mathrm{ml}$.

Testicle biopsy: (Slide No. 8882)-Numerous tubules, of which the lumen was decreased. The tubule wall showed partial sclerosis and on that account only one peripheral layer of Sertoli cells; some evidence of all stages of spermatogenesis in the tubules, including spermatozoa. Interstitial tissue exhibiting few Leydig cells.

Course of disease: Given treatment with methyltestosterone which raised the fructose level to $1750 \mathrm{\mu g} / \mathrm{ml}$. In the first 3 months of treatment wife became pregnant; birth of healthy son at appointed time.

The etiology of this disease has remained vague up to now. In one single case, which was treated with chorionic gonadotrophin as well as with methyltestosterone, a normal fructose concentration was attained after a long-standing focus (several bad teeth, suppuration of maxillary sinus) had been eliminated, and pregnancy was achieved. In this case there is probably an explanation for the long unexplained Leydig-cell deficiency: it can be assumed that a partial deficiency of the anterior pituitary (gonadotrophic function-lack of ICSH) had been induced by toxins, which were removed by the aforesaid hormone treatment. After eliminating the focus, which must have been responsible for the toxic state, the anterior pituitary functioned normally once again (normal level of fructose in seminal plasma), and a continued hormone treatment was not necessary.

\section{IMPORTANCE OF FRUGTOSE TEST IN THE EVALUATION OF FERTILITY}

On the basis of the preceding experimental and diagnostic findings, a modern fertility examination must be considered incomplete with the mere morphological examination of the ejaculate; on the contrary a biochemical analysis of the semen is a necessity in order to exclude a postpubescent interstitial-cell deficiency.

We believe that our study can be considered significant because more than 2000 patients were examined in our fertility consultations. Morphological and biochemical examinations showed the presence of normospermia with a postpubescent interstitial-cell deficiency in fifty-eight cases $(2 \cdot 74 \%)$. These 
childless couples had wanted children in their many years of marriage. The use of controls helped to substantiate the findings made. Chorionic gonadotrophin and methyltestosterone raised the level of fructose into the normal range. The patients thereby became fertile as shown by the occurrence of numerous births after treatment. In our opinion there is no doubt that a true fertility disturbance was present in these cases.

\section{REFERENCES}

Belonoschkin, B. (1954) Männliches Klimakterium. Münch. med. Wschr., p. 1468.

Davts, M. E. \& McCune, W. W. (1950) Metabolism of human spermatozoa in semen. Fertil. Steril. $1,158$.

Davis, M. E. \& McCune, W. W. (1950b) Fructolysis of human spermatozoa. Fertil. Steril. 1, 362.

Eichenberger, E. \& Goossens, O. (1950) Fructose und Fructolyse im menschlichen Samen. Schweiz. med. Wschr. 80, 1073.

Gropper, H. \& NtKolowski, W. (1954) Ejakulatfructose und Fertilitätsdiagnostik. Dtsch. med. Wschr., p. 1926.

Hamburger, G. (1948) Normal urinary excretion of neutral 17 -ketosteroids with special reference to age and sex variation. Acta endocr. $1,19$.

Harvey, G. (1951) Fructose and critic acid in human semen. Proc. Soc. Study Fertil. 3, 56.

Huggins, C. B. \& Johnson, C. (1933) Chemical observations on fluids of the seminal tract. Amer. 7. Physiol. 103, 574.

Ivanov, E. E. (1931) Zur Frage der Energetik der Spermatozoenbewegung. Z. Zucht. B, 20, 404.

JoHNSEN, S. G. (1956) Fractionation of urinary 17-ketosteroids. II. Normal values for men and women at different ages. Acta endocr. 21, 146.

Kıмmig, J. (1955) Die Biochemie des menschlichen Spermas. Proc. Ist Symp. dtsch. Ges. Endokr. Springer, Berlin.

Kimmig, J. (1956) Zur Diagnose und Therapie der Fertilitätsstörungen des Mannes. Arch. Gynaek. 18, 238.

Kimmic, J. (1959) Klinische Beobachtungen zur Diagnose und Therapie der Leydig-Zell-Insuffizienz. Klin. Wschr., p. 1165.

Kuinefelter, H. F., Albright, F. \& Griswold, G. C. (1943) Quantitative test for normal or decreased amounts of follicle-stimulating hormone in urine. 7. clin. Endocrin. 3, 529.

Landau, R. L. \& Loughead, R. (1951) Seminal fructose concentration as an index of androgenic activity in man. F. clin. Endocrin. 11, 1411.

McGullagh, E. P. \& Schaffenburg, G. A. (1951) Hormonal activity in semen. F. clin. Endocrin. $11,403$.

McCullagh, E. P., Beck, J. C. \& Schaffengurg, C. A. (1953) A syndrome of eunuchoidism with spermatogenesis, normal FsH and low or normal rCSH ('Fertile Eunuchs'). F. clin. Endocrin. 13, 489.

Mann, T. (1946a) The origin and function of seminal fructose. Biochem. F. 40, 29.

MANN, T. (1946b) Studies on the metabolism of semen. Fructose as a normal constituent of seminal plasma. Site of formation and function of fructose in semen. Biochem. F. 40, 481.

Mann, T. (1954) The biochemistry of semen. Methuen, London.

Mann, T. \& Parsons, U. (1947) Effect of testicular hormone on the formation of seminal fructose. Nature, Lond. 160, 294.

Mann, T. \& Parsons, U. (1950) Studies on the metabolism of semen. Role of hormones. Effect of castration, hypophysectomy and diabetes. Relation between blood, glucose and seminal fructose. Biochem. 7. 46, 440 .

Mann, T., Davies, D. V. \& Humphrey, G. F. (1949) Fructose and citric acid assay in the secretions of the accessory glands of reproduction as indicator tests of male sex hormone activity. F. Endocrin. $6,75$.

Mann, T., Lutwak-Mann, G. \& Price, D. (1948) Secretion of fructose and citric acid in transplants of rat seminal vesicle and coagulation gland. Proc. Soc. exp. Biol., N.Y. 68, 413.

Nowakowski, H. \& Schirren, C. (1956) Spermaplasmafructose and Leydig-Zell-funktion beim Manne. Klin. Wschr., p. 19.

Nowakowski, H. \& Schmmt, H. (1959) Die Hodenveränderungen beim alternden Mann und deren klinische Bedeutung. Schweiz. med. Wschr., p. 1204.

Pasqualini, R. Q. (1953) Hypoandrogenic syndrome with normal spermatogenesis. 7. clin. Endocrin. $13,128$.

Raboch, J. \& Hradec, J. (1954) Quantitative Fructosebestimmungen im menschlichen Ejakulate. Endokrinologie, 31, 171. 
Schaffenburg, C. A. \& McCullagh, E. P. (1954) Studies in sperm hormones: demonstration of oestrogenic activity. Endocrinology, 54, 296.

Schirren, G. (1955) Biochemische Untersuchungen am menschlichen Sperma: Fructose. Medizinische, p. 872.

Schirren, C. (1957) Zur Diagnostik und Therapie von Fertilitätsstörungen des Mannes. Z. Hautkrkh. 23, 345.

Schirres, C. (1959) Untersuchungen zur Biochemie des menschlichen Spermaplasmas. Proc. IIIrd World Congr. Fertil. Steril., Amsterdam.

Schirren, C. (1961) Fertilitätsstörungen des Mannes. Diagnostik, Biochemie des Spermaplasmas, Hormontherapie. Enke, Stuttgart.

Stossier, F. (1960) Untersuchungen zum Einfluss der Carenz auf die Qualität des menschlichen Spermas. Inaug. Diss., Hamburg.

Tilluinger, K. G. (1957) Testicular morphology. Acta endocr. Suppl. 30.

Tyler, E. T. (1955) Seminal fructose studies in infertility. Fertil. Steril. 6, 247.

Vaishwanar, P. S. (1958) Fructolysis of human spermatozoa in semen. Amer. F. Obstet. 75, 139.

Vasterling, H. W. (1958) Zur Diagnostik und Therapie von männlichen Fertilitätsstörungen. Med. Mitt. 19, 103. 